\title{
Activity patterns of wild European lobster Homarus gammarus in coastal marine reserves: implications for future reserve design
}

\author{
Even Moland ${ }^{1, *}$, Esben Moland Olsen ${ }^{1,2}$, Halvor Knutsen ${ }^{1,2}$, Jan Atle Knutsen ${ }^{3}$, \\ Svein Erik Enersen ${ }^{1}$, Carl André ${ }^{4}$, Nils Chr. Stenseth ${ }^{2}$ \\ ${ }^{1}$ Institute of Marine Research, Nye Flødevigvei 20, 4817 His, Norway \\ ${ }^{2}$ Centre for Ecological and Evolutionary Synthesis (CEES), Department of Biology, University of Oslo, PO Box 1066 Blindern, \\ 0316 Oslo, Norway \\ ${ }^{3}$ Department of Environment, County Governor of Aust-Agder, PO Box 788 Stoa, 4809 Arendal, Norway \\ ${ }^{4}$ Department of Marine Ecology-Tjärnö, University of Gothenburg, 45296 Strömstad, Sweden
}

\begin{abstract}
European lobster Homarus gammarus in Norway has been in decline over the last 30 to $40 \mathrm{yr}$, and the species is currently red listed according to International Union for Conservation of Nature criteria. In 2006, experimental lobster reserves were established in the coastal Skagerrak, southern Norway, allowing for studies in the absence of disturbance by fishing gear. We present behavioural data from individual lobsters $(n=10)$ within 2 of the reserves. These data were obtained from data storage tags which logged in situ temperature and depth of specific individuals for up to 1 yr. To the best of our knowledge, these are the first direct measurements of depth obtained from freely behaving lobsters. Net movement exhibited by recaptured lobsters, measured as the distance between global positioning system positions recorded at the site of capture and recapture ranged from 15 to $580 \mathrm{~m}$. Lobsters used habitats within a depth range of 1 to $57 \mathrm{~m}$, and experienced sea temperatures ranging from $2^{\circ} \mathrm{C}$ during late winter (February to March) to $18^{\circ} \mathrm{C}$ during late summer (August to September). Lobster activity levels declined from September, reaching a minimum during February and March. From April, activity levels resumed. Seasonal variation in activity was correlated to water temperature $\left(\mathrm{r}^{2}=0.55\right)$. Lobsters were more active during nighttime than during daytime, and there was a tendency for lobsters to reside in more shallow water during nighttime versus daytime. The present study suggests that future reserves for European lobster should be designed to include deeper habitat $(30$ to $50 \mathrm{~m}$ ) in areas where such habitat exists when the management objective is long-term protection.
\end{abstract}

KEY WORDS: Archival tag - Behaviour - Marine reserve design - Diel rhythm - Data storage tag · Decapoda $\cdot$ Data storage tag $\cdot$ DST

Resale or republication not permitted without written consent of the publisher

\section{INTRODUCTION}

Marine reserves offer unique opportunities for longterm studies on commercially exploited species in the absence of harvest mortality and disturbance by fishing gear. Conducting studies on species in an unexploited state has the potential to generate valuable, fundamental knowledge regarding their ecology and behaviour, undisturbed and unbiased by extractive activities in their habitats, such as baited traps designed to attract and capture lobsters. Such knowledge is limited for most marine species, but essential in the process of tailoring spatial conservation and management measures. Over the last decade, marine reserves have received unparalleled attention as a promising tool in fisheries management and conservation. A plethora of studies which document the effects, discuss the design, and explore the potential applications of 
marine reserves have been presented (e.g. Côté et al. 2001, Halpern \& Warner 2003, Russ et al. 2008, Game et al. 2009). A recognised challenge for the success of marine reserves as a fisheries management tool is the lack of data on the spatio-temporal distribution of the target species (Sale et al. 2005). Moreover, knowledge regarding activity patterns, habitat preference, and the nature and magnitude of movements between fished and unfished areas of the target species is central for successful reserve design (Kramer \& Chapman 1999, Lowe et al. 2003). Further, such knowledge may also serve as a predictive tool for assessing the potential effect of marine reserves in nearby exploited areas.

European lobsters Homarus gammarus are large decapod crustaceans of ecological and commercial importance, distributed from the north of Norway to Morocco in North Africa (Triantafyllidis et al. 2004). Historically, the Skagerrak region supported a viable population of the species, but over the last 30 to $40 \mathrm{yr}$ catches have plummeted (Agnalt et al. 2007). Currently, the stock ranks on the Norwegian Red List as 'near threatened' according to IUCN (International Union for Conservation of Nature) criteria (Oug et al. 2010). The decline in catches has been reflected in the standardised catch-per-unit-effort survey performed in the Skagerrak since 1928, suggesting that the lobster population is presently at a historical low (Pettersen et al. 2009). Overall, marine ecosystems in the North Sea and the Skagerrak region are profoundly impacted and altered by human activities (Halpern et al. 2008). Subsequently, the region has seen collapses in stocks of ecologically and commercially important fish species during the second half of the last century (Cook et al. 1997, Nesbø et al. 2000, Fromentin 2009, Olsen et al. 2009, Payne et al. 2009).

In September 2006, 4 experimental lobster reserves ( 0.5 to $1 \mathrm{~km}^{2}$ area) were established along the Norwegian Skagerrak coast in order to generate knowledge regarding population dynamics, behaviour and the development of local lobster populations in areas unaffected by extractive fishing. The reserves were established based on consultations with local fishers, and policing of the lobster reserves are performed by the Coast Guard and local police (Pettersen et al. 2009).

The European lobster is considered a nocturnal animal (Mehrtens et al. 2005, Childress \& Jury 2006). Daylight hours are generally spent solitarily inside dens or shelters on rocky bottoms, and activity increases at sunset and continues during the dark hours (Smith et al. 1998, 1999). The major benefit of this diel activity pattern is probably reduced predation risk from visual predators active during the day, but increased prey availability at night could also make foraging during the dark hours more energetically effective and further promote nocturnal activity (Smith et al. 1998).
Seasonal variations in lobster activity patterns are presumably linked to species-specific temperature requirements. In their review, Haakonsen \& Anoruo (1994) thus concluded that the most informative and meaningful parameters for understanding lobster activity are probably temperature and vertical displacement (depth) rather than horizontal displacement. Detailed information on short-term and seasonal movement patterns in freely behaving European lobsters has been sparse. Although past studies indicate that the European lobster can be considered relatively stationary (Dannevig 1936, Smith et al. 1998, Smith et al. 2001, Agnalt et al. 2007), it is widely accepted that American lobsters Homarus americanus migrate in order to achieve adequate water temperatures to meet the physiological requirements of moulting, mating, egg extrusion and embryonic development (Cooper \& Uzmann 1971, Lawton \& Lavalli 1995, Cowan et al. 2006).

In the present study, we employed archival data storage tag technology in 2 of the recently established lobster reserves in the coastal Skagerrak. The objectives were: (1) to obtain and analyse long-term data on activity patterns of wild European lobster in their natural habitat, undisturbed by fishing gear, and (2) to assess whether the habitat at depths included within reserve boundaries were sufficient to fulfill the lobsters' requirements throughout the 4 seasons. Lobsters were found to use habitats within a depth range of 1 to $57 \mathrm{~m}$ (mostly within 10 to $40 \mathrm{~m}$ depth) and experienced sea temperatures ranging from $2^{\circ} \mathrm{C}$ during late winter (February to March) up to $18^{\circ} \mathrm{C}$ during late summer (August to September). The lobsters' activity level declined from September, reaching a minimum during February and March. From April, activity levels resumed. Lobsters were more active during nighttime than during daytime, and there was a tendency for lobsters to reside in slightly shallower water during nighttime versus daytime.

\section{MATERIALS AND METHODS}

The present study was conducted within 2 recently established Norwegian lobster reserves: Flødevigen $\left(58^{\circ} 25^{\prime} 196^{\prime \prime} \mathrm{N}, 08^{\circ} 45^{\prime} 874^{\prime \prime} \mathrm{E}\right)$ and Kvernskjær (59 02' $144^{\prime \prime}$ N, $10^{\circ} 58^{\prime} 604^{\prime \prime} \mathrm{E}$ ), on the Skagerrak coast (Fig. 1C). The Flødevigen reserve is the larger of the two, covering $1 \mathrm{~km}^{2}$. Most of this reserve is sheltered from the Skagerrak Sea by an archipelago. The Kvernskjær reserve is smaller $\left(0.5 \mathrm{~km}^{2}\right)$ and more exposed to the Skagerrak Sea. Both reserves ares naturally delineated by a bathymetry profile shaped by glacial scouring. The Flødevigen reserve contains a main gully that gains depth as it cuts from northwest to southeast, emptying 

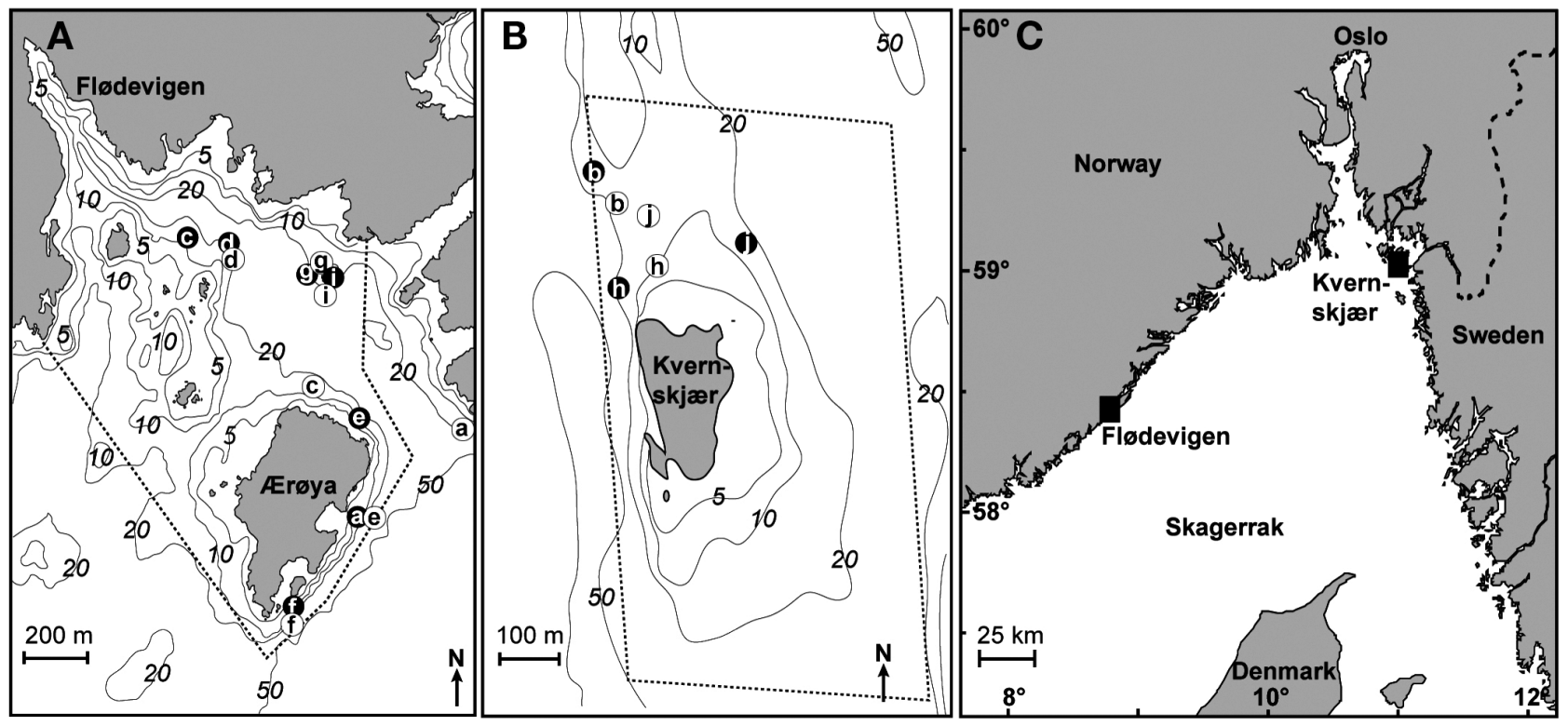

Fig. 1. The 2 European lobster Homarus gammarus reserves, in which lobsters were equipped with data storage tags from 2006 to 2007; (A) Flødevigen, (B) Kvernskjær, and (C) their locations in the Skagerrak. Dotted lines indicate reserve borders. Black and white circles represent positions of individual lobsters (ID a to j) capture and recapture, respectively (see also Table 2). Numbers are contour depths $(\mathrm{m})$

into the deeper basin north of Ærøya Island. Depths increase gradually and range from 0 to maximum $50 \mathrm{~m}$. The greatest depths are found on the reserve boundary perpendicular to the steep slope on the exposed side of Ærøya Island (Fig. 1A). The upper 1 to $5 \mathrm{~m}$ of substrate within the Flødevigen reserve are mostly rocky habitat dominated by macro-algae. Photosynthetic communities become gradually sparser down to $10 \mathrm{~m}$ and are more or less absent at greater depths, except for the exposed southeastern side of Ærøya Island, which contains a lush kelp forest that extends down to 10-12 m. The Kvernskjær reserve differs from the Flødevigen reserve in its location around a single small island (Kvernskjær) flanked by a particularly steep slope and deep channel (>50 m) on the western side (Fig. 1B). Macro-algae are sparse near the surface in the Kvernskjær reserve due to constant discharge of freshwater from the Glomma River. However, macro-algae are present from 1 to $10 \mathrm{~m}$, and the submerged plateau at the southern end of Kvernskjær Island contains a sparse kelp forest. SCUBA surveys performed in both areas prior to reserve establishment revealed a topography consisting of rock faces and ledges with rocks or boulder fields of varying size at the base. In deeper basins and flat areas the bottom consists of soft sediments. Both reserves harbour typical lobster habitats representative of the coastal Skagerrak, which was one of the selection criteria used when the experimental reserves were established (Pettersen et al. 2009). The usual tidal change in the Skagerrak is $<0.5 \mathrm{~m}$.
The individual lobsters Homarus gammarus used in the present study were captured with mackerel-baited parlour pots within the Flødevigen ( $\mathrm{n}=23)$ and Kvernskjær $(n=34)$ reserves during late August and early September 2006 (Table 1). Pots were deployed at depths between 10 and $30 \mathrm{~m}$ and soaked overnight. All captured lobsters were measured (total length), and their sex was determined. Body sizes were converted from total length (measured from the tip of the rostrum to the end of the telson) to carapace length (CL; measured from the rear of the eye socket to the posterior margin of the carapace) using sex-specific regressions

Table 1. Homarus gammarus. Summary details of European lobsters equipped with data storage tags within 2 marine reserves in the coastal Skagerrak, showing the number of tagged individuals (n), the mean carapace length of each group $\left(L_{\mathrm{CL}}\right)$ of individuals, the standard deviation (SD) and the range of carapace lengths (CL). Note that minimum legal length was $24 \mathrm{~cm}$ total length in 2006, corresponding to $\sim 87$ and $\sim 85 \mathrm{~mm}$ CL for males and females, respectively

\begin{tabular}{|lrrrl|}
\hline Group (sex and state) & $\mathrm{n}$ & $L_{\mathrm{CL}}$ & $\mathrm{SD}$ & $\mathrm{CL}$ \\
\hline Kvernskjær & & & & \\
Males & 11 & 85 & 9 & $75-104$ \\
Ovigerous females & 7 & 86 & 9 & $70-97$ \\
Non-ovigerous females & 16 & 88 & 7 & $75-107$ \\
Flødevigen & & & & \\
Males & 10 & 91 & 8 & $76-99$ \\
Ovigerous females & 8 & 94 & 12 & $84-119$ \\
Non-ovigerous females & 5 & 97 & 11 & $81-107$ \\
\hline
\end{tabular}


of total length versus CL for European lobster in the eastern Skagerrak (Mats Ulmestrand, Swedish Board of Fisheries, unpubl. data). Adult lobsters that had recently moulted (identified by exoskeletons with a fresh appearance and without epibionts) were used to provide the longest possible intermoult period (Curtis \& McGaw 2008). Attempting to achieve a semi-balanced design with regard to sex and reproductive state, we selected males $(\mathrm{n}=21)$, ovigerous females $(\mathrm{n}=15)$ and non-ovigerous females $(\mathrm{n}=21)$ (Table 1). A data storage tag (DST) which logged pressure (depth) and temperature (LTC 1100, Lotek) was attached dorsally with stainless wire between the most robust denticles on the carpus segment of the crusher cheliped of each lobster (Fig. 2). The sensor accuracy is estimated by the manufacturer to be $\pm 0.3^{\circ} \mathrm{C}$ for temperature and $\pm 1 \%$ pressure accuracy of current scale. In addition, 11 lobsters in the Flødevigen reserve were also tagged with a V13 individually coded acoustic transmitter (Vemco; $13 \mathrm{~mm}$ diameter; $36 \mathrm{~mm}$ length; $<6 \mathrm{~g}$ weight in seawater; $320 \mathrm{~d}$ expected battery life). The tag was inserted into a piece of plastic tubing and affixed dorsally to the carpus segment of the cutter cheliped with a plastic cable tie. These 11 lobsters were thus equipped with both types of tags. Handling time did not exceed $5 \mathrm{~min}$. After the tagging procedure, all lobsters were gently released from the surface within $10 \mathrm{~m}$ of their capture position. The attached tags did not appear to influence behaviour or manoeuvrability of lobsters as evidenced by observations in the laboratory prior to the field study. This observation was supported by others conducting similar tagging procedures on American lobsters (Cowan et al. 2006). All tags were lost after moulting. Tagging was performed during a survey in the lobster reserves conducted annually by the Norwegian Institute of Marine Research. As part of this survey, all lobsters additionally received a T-bar anchor tag (TBA1, $30 \times 2 \mathrm{~mm}$, Hallprint Pty) with printed information about the ongoing project. The T-bar anchor tag was inserted in the ventral musculature between the cephalothorax and the first abdominal segment, to the right side of the midline using a standard tag applicator. Placing the tag in this area ensures its retention through the moulting process. Data from telemetry and T-bar tagging will be reported elsewhere in separate studies.

Lobsters had to be recaptured to retrieve information from the DSTs. For this purpose we adopted 3 strategies. First, we conducted 2 trap surveys during 2007 (June and August). Second, we informed local fishers about the project, in case any of the tagged lobsters should leave the reserves and become exposed to harvesting. Third, lobsters tagged with additional acoustic transmitter tags in the Flødevigen reserve were tracked from the surface using a handheld hydrophone (VH 110, Vemco) coupled to an ultrasonic receiver (VR 100, Vemco). Once a lobster was accurately located, we marked the position by gently lowering a weighted bottom rope and searched for the lobster using SCUBA. We recorded global positioning system (GPS)

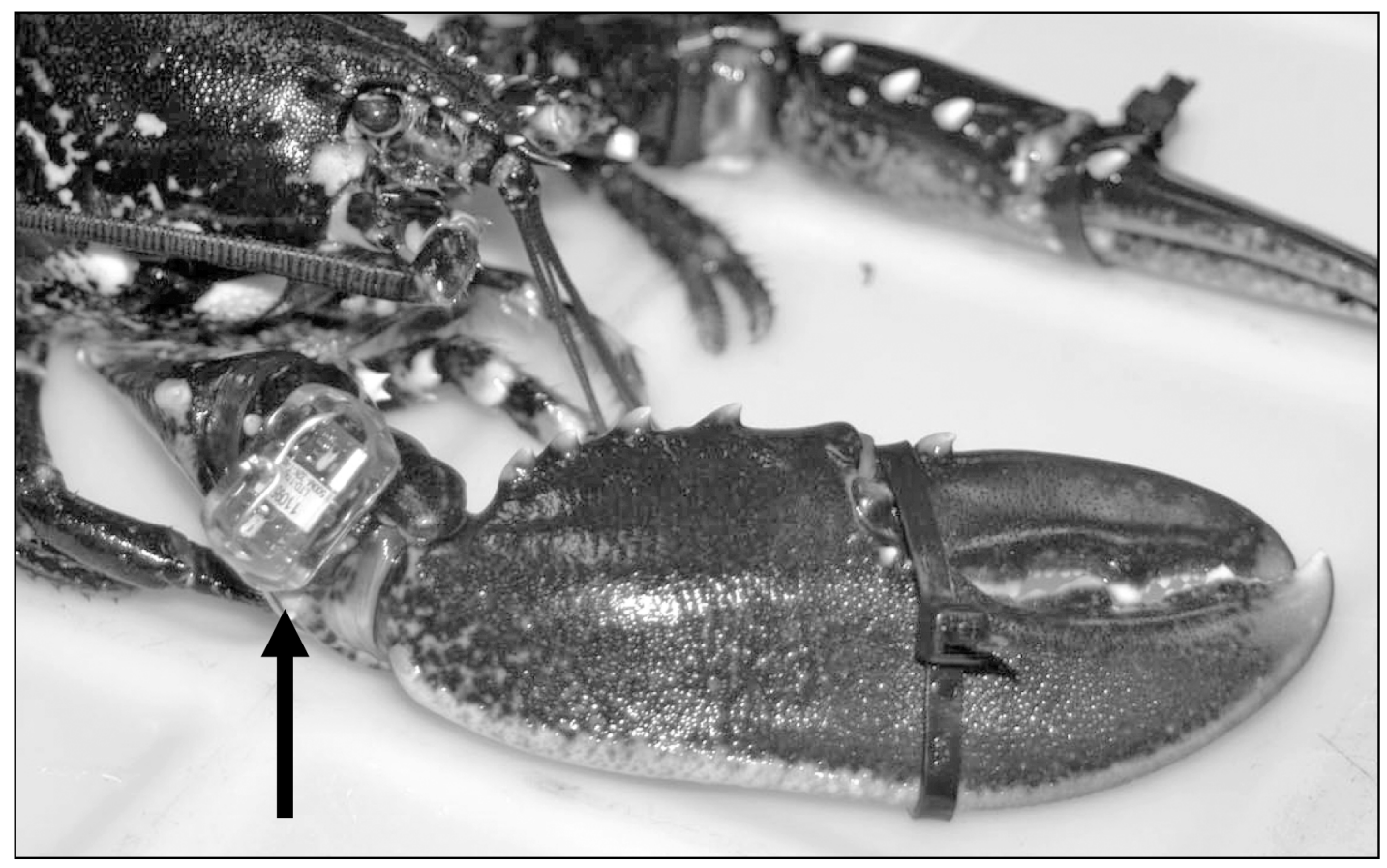

Fig. 2. Homarus gammarus. Data storage tag (LTC 1100, Lotek; black arrow) attached to a European lobster (Photo: E. Moland) 
positions for recaptures in all modes of recapture. Out of the 10 recaptured lobsters, there was only 1 male. One possible explanation for this could be that males were more likely to have reduced catchability due to moulting at the time around the trap surveys conducted in June and August 2007. During the SCUBA searches for lobsters tagged with both DST and telemetry tags, we were able to locate 2 shed telemetry tags on the substratum near dens occupied by males during moulting. We were certain of which individuals these lost tags were originally attached to based on: (1) the specific code transmitted by the tags and (2) their serial numbers, which were still readable. Unfortunately, we were unable to locate the shed DSTs lost by these males near the same shelters.

Data were extracted from tags attached to recaptured individuals and processed within the R software (Version 2.12.0, www.r-project.org/). After data extraction, recaptured lobsters were released at the site of capture with the tag intact, in case they should be recaptured again at a later point in time. The DSTs record pressure (depth) and temperature 256 times per hour until the memory is full. When this happens, the logger doubles its sampling interval and deletes every second observation that has been stored. This process repeats itself as long as the battery lasts (16 mo) or until the tag is recovered. We found that after $1 \mathrm{yr}$, the logger still contained ca. 50 stored observations per day. We deleted the observations close to release and recapture (1 to $3 \mathrm{~d}$ ), allowing the lobsters to resume normal behaviour after tagging and accounting for the fact that several of them would be locked within traps when recaptured.

To relate lobster behaviour to ambient sea temperature in the Skagerrak, we used observations from 1, 19 and $75 \mathrm{~m}$ depths, recorded daily by the Institute of Marine Research, Flødevigen (Fig. 3).

We used classical linear models (McCullagh \& Nelder 1999) to analyse the effects of individual size and time at large on net horizontal displacement. Time at large (number of days from release to recapture) and horizontal displacement $(\mathrm{m})$ were ln-transformed in order to stabilise the variances, and residual plots indicated that the model fitted the data adequately. We tested for an effect of size (CL) and time at large (Days) on horizontal displacement (Dist) using the following model structure:

$$
\begin{aligned}
\ln \left(\text { Dist }_{i}\right)= & \beta_{0}+\beta_{1}\left(\mathrm{CL}_{i}\right)+\beta_{2}\left[\ln \left(\text { Days }_{i}\right)\right] \\
& +\beta_{3}\left[\mathrm{CL}_{i} \times \ln \left(\text { Days }_{i}\right)\right]+\varepsilon_{i}
\end{aligned}
$$

where $\beta_{0}$ is the intercept, $\beta_{1}$ is the slope relating to individual size $(\mathrm{CL}), \beta_{2}$ is the slope relating to ln-transformed time at large (Days), $\beta_{3}$ is the slope relating to the interaction between individual size (CL) and ln- transformed time at large (Days) and $\varepsilon_{i}$ is the error term for individual $i$.

Lobster activity level was estimated as the range of recorded depths during specific time intervals, i.e. the maximum depth to the minimum depth. This method was chosen after visual examination of individual daily depth recordings (see Fig. 4). In order to compare the seasonal trend in activity level to the seasonal trend in water temperature, we calculated the mean daily depth range for all individuals for the period during which we had data for at least 2 lobsters (29 August 2006 to 27 June 2007), and the mean daily water temperature (based on measurements from 1, 19 and $75 \mathrm{~m}$ depths in Flødevigen; Fig. 3) during the same period. We used classical linear models (McCullagh \& Nelder 1999) to analyse the effect of mean water temperature on mean depth range. Mean daily depth range $(\mathrm{m})$ and mean daily water temperature $\left({ }^{\circ} \mathrm{C}\right)$ were $\ln$-transformed in order to stabilise the variances, and residual plots indicated that the model fitted the data adequately. To test for an effect of mean daily water temperature (Temp) on the mean daily depth range (Depth), we used the following model structure:

$$
\ln \left(\operatorname{Depth}_{i}\right)=\beta_{0}+\beta_{1}\left[\ln \left(\operatorname{Temp}_{i}\right)\right]+\varepsilon_{i}
$$

where $\beta_{0}$ is the intercept, $\beta_{1}$ is the slope relating to lntransformed mean water temperature (Temp) and $\varepsilon_{i}$ is the error term for individual $i$.

In order to compare the activity level between daytime and nighttime, we estimated a diel activity contrast (DAC) as the difference between the depth range (DR) occupied during daytime (09:00 to 15:00 h) and the depth range occupied during the following night (21:00 to $03: 00 \mathrm{~h}): \mathrm{DAC}=\mathrm{DR}_{\text {day }}-\mathrm{DR}_{\text {night }}$. Similarly, we estimated a diel depth contrast (DDC) as the difference between the mean depth (MD) occupied during daytime and that occupied during the following night. The

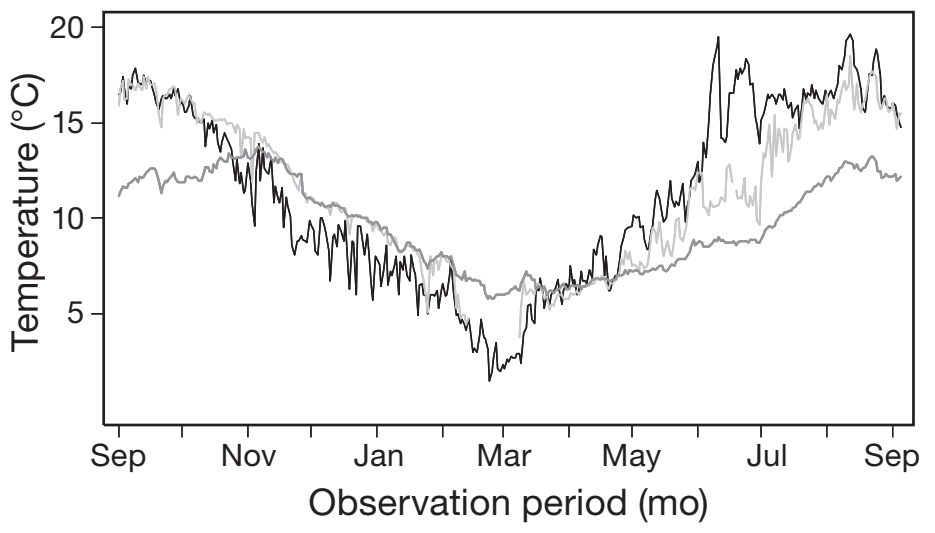

Fig. 3. Seasonal variation in sea temperature at 1 (black line), 19 (light grey line) and $75 \mathrm{~m}$ depths (dark grey line) recorded in the Flødevigen lobster reserve during the study period (2006 to 2007). Tick marks on the $x$-axis mark the beginning of each month 

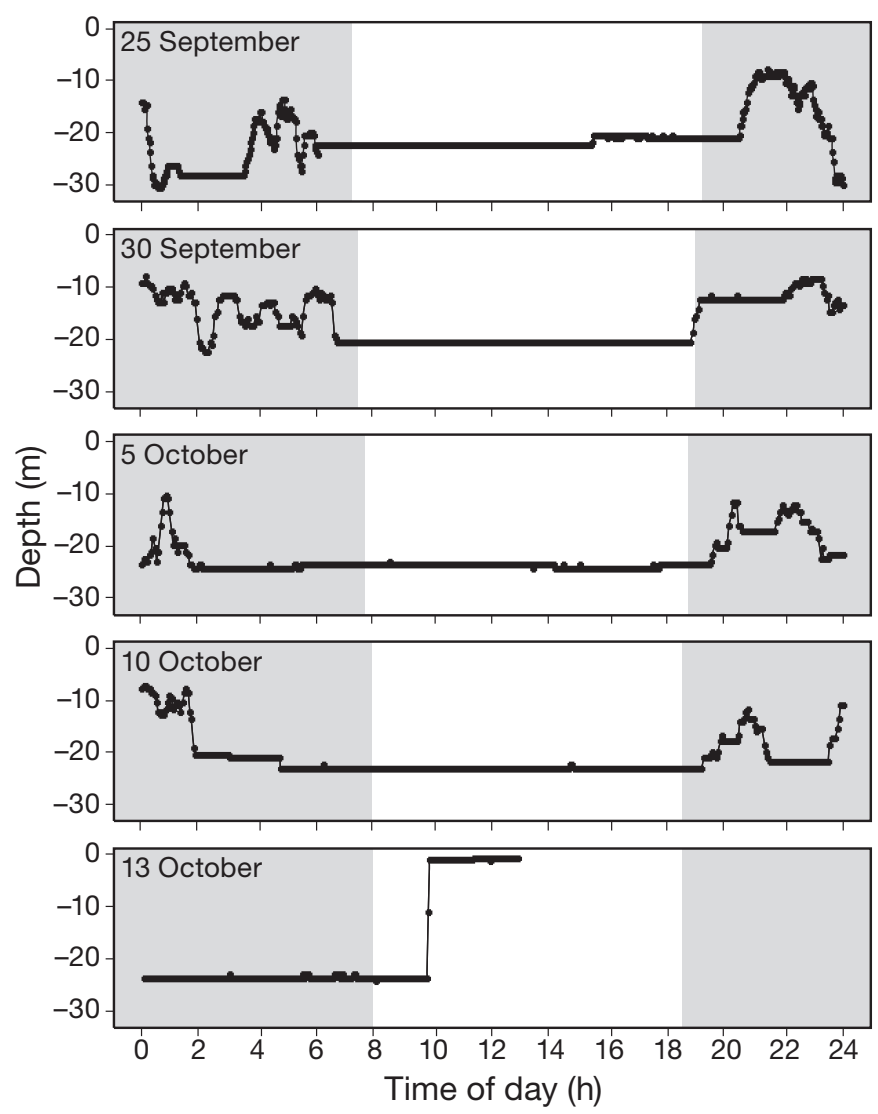

Fig. 4. Homarus gammarus. Depths recorded for an individual lobster (ID e) on $5 \mathrm{~d}$ from September to October 2006. The bottom panel (13 October) shows depth data recorded while the lobster was locked in a trap (to approximately 10:00 h) and during and after research survey trap haul (at 10:00 h) (see Table 2). Shaded areas indicate nighttime, and white areas indicate daytime (from sunrise to sunset). Tick marks on the $x$-axis mark the beginning of each hour

observation period for these diel comparisons was set to $26 \mathrm{~d}$ between October and November 2006, when we had overlapping data for 9 recaptured females. Linear mixed-effects models were used to test for differences in activity level and habitat use between daytime and nighttime. Here, individual number (id) was set as a random effect to control for variation from repeated measurements (Pinheiro \& Bates 2000). The depth range data (DR) were ln-transformed in order to stabilise the variance, and 0.5 was added to all observations in order to avoid zero values. Residual plots indicated that the models fitted the data adequately. We first tested for an effect of time of day (DN) on activity level (DR) using the following model structure:

$$
\ln \left(\mathrm{DR}_{i j}\right)=\beta_{0}+\beta_{1}\left(\mathrm{DN}_{i j}\right)+\beta_{2}\left(\mathrm{D}_{i j}\right)+\alpha_{i}+\varepsilon_{i j}
$$

where $\beta_{0}$ is the intercept, $\beta_{1}$ is the slope relating to time of day (DN) set as a binary factor indicating daytime or nighttime, $\beta_{2}$ is the slope relating to day of the year (D), $\alpha_{i}$ is the random effect of individual ID and $\varepsilon_{i j}$ is the error term for individual $i$ on Day $j$. Next, we tested for an effect of DN on mean depth (MD) using the same model structure as in Eq. (3):

$$
\mathrm{MD}_{i j}=\beta_{0}+\beta_{1}\left(\mathrm{DN}_{i j}\right)+\beta_{2}\left(\mathrm{D}_{i j}\right)+\alpha_{i}+\varepsilon_{i j}
$$

where $\beta_{0}$ is the intercept, $\beta_{1}$ is the slope relating to $D N$ set as a binary factor indicating daytime or nighttime, $\beta_{2}$ is day of the year (D), $\alpha_{i}$ is the random effect of individual ID and $\varepsilon_{i j}$ is the error term for individual $i$ on Day $j$.

\section{RESULTS}

A total of 10 DST tagged lobsters Homarus gammarus, ranging in size from 81 to $107 \mathrm{~mm}$ (CL), were recaptured during 2006 and 2007 with the tag intact. Lobsters were recaptured in trap surveys $(n=5)$, by a local fisher $(\mathrm{n}=1)$ and by a combination of ultrasonic tracking and SCUBA $(\mathrm{n}=4)$ (Table 2).

The net horizontal displacement (net movement) exhibited by recaptured lobsters, measured as the distance between GPS positions recorded at the site of capture and recapture (to the nearest $5 \mathrm{~m}$ ), was very limited in most cases and ranged from 15 to 580 m (mean \pm SD: $187 \pm 195 \mathrm{~m}$ ) (Table 2). There was no effect of lobster size or time at large on net horizontal displacement ( $p>0.4)$, and no interaction effect was found of lobster size and time at large on net horizontal displacement $(p>0.5)$.

For two of the lobsters (ID $\mathrm{c}$ and $\mathrm{h}$ ) observed in the present study, depths beyond the range of those available within reserve boundaries were recorded, showing that these lobsters must have left the reserve areas for prolonged periods during winter (see Fig. 4). In addition, a third lobster (ID a) left the Flødevigen reserve and was recaptured by a lobster fisher outside reserve borders (in shallow water) early in the study (see Fig. 1).

Depths recorded for the lobsters varied considerably, both among individuals and on diel and seasonal scales. The mean depth recorded throughout the study period was $27.4 \mathrm{~m}$ (range: 1 to $57 \mathrm{~m}$ ). The maximum depth $(57 \mathrm{~m})$ was recorded by a DST carried by a $106 \mathrm{~mm}$ (CL) female (ID h) during a prolonged stay (December 2006 to April 2007) below $50 \mathrm{~m}$ depth (Fig. 5). Apart from this, lobsters generally spent most of their time at depths from about $35 \mathrm{~m}$ up to about $15 \mathrm{~m}$ (Fig. 5). Some excursions into more shallow waters were also recorded from May to September (Fig. 5). On a seasonal basis, the activity level of the lobsters dropped markedly from September to March, reaching a minimum during the cold winter months of February and March (Fig. 6). The period of minimum daily depth change followed immediately after the period during which the lowest ambient water temper- 
Table 2. Homarus gammarus. Summary details of 10 recaptured lobsters (ID a to j) equipped with data storage tags. Fl: Flødevigen; Kv: Kvernskjær; F: non-ovigerous female; O-F: ovigerous female; M: male; CL: carapace length; Dur: duration of in situ data logging; Dist: distance between capture and recapture GPS positions (net movement) (see also Fig. 1)

\begin{tabular}{|c|c|c|c|c|c|c|c|c|}
\hline ID & Site & Sex/state & $\begin{array}{c}\text { Size } \\
(\mathrm{mm} \mathrm{CL})\end{array}$ & $\begin{array}{c}\text { Release } \\
\text { (dd/mm/yy) }\end{array}$ & $\begin{array}{l}\text { Recapture } \\
\text { (dd/mm/yy) }\end{array}$ & Recapture mode & $\begin{array}{l}\text { Dur } \\
\text { (d) }\end{array}$ & $\begin{array}{l}\text { Dist } \\
(\mathrm{m})\end{array}$ \\
\hline $\mathrm{a}$ & $\mathrm{Fl}$ & F & 81 & 05/09/06 & $17 / 11 / 06$ & Fisherman & 70 & 405 \\
\hline $\mathrm{b}$ & $\mathrm{Kv}$ & $\mathrm{O}-\mathrm{F}$ & 86 & 29/08/06 & $28 / 06 / 07$ & Trap survey & 302 & 60 \\
\hline $\mathrm{C}$ & $\mathrm{Fl}$ & $\mathrm{O}-\mathrm{F}$ & 88 & $12 / 10 / 06$ & 08/06/07 & SCUBA & 238 & 580 \\
\hline $\mathrm{d}$ & $\mathrm{Fl}$ & $\mathrm{F}$ & 90 & $12 / 10 / 06$ & $19 / 06 / 07$ & SCUBA & $238^{\mathrm{a}}$ & 15 \\
\hline e & $\mathrm{Fl}$ & M & 93 & 06/09/06 & $13 / 10 / 06$ & Trap survey & 36 & 325 \\
\hline $\mathrm{f}$ & $\mathrm{Fl}$ & $\mathrm{O}-\mathrm{F}$ & 102 & $12 / 10 / 06$ & 06/09/07 & Trap survey & 328 & 20 \\
\hline g & $\mathrm{Fl}$ & $\mathrm{F}$ & 104 & $12 / 10 / 06$ & $28 / 06 / 07$ & SCUBA & 258 & 45 \\
\hline $\mathrm{h}$ & $\mathrm{Kv}$ & $\mathrm{F}$ & 106 & 28/08/06 & $28 / 08 / 07$ & Trap survey & $304^{\mathrm{a}}$ & 70 \\
\hline $\mathrm{i}$ & $\mathrm{Fl}$ & F & 107 & $12 / 10 / 06$ & $28 / 06 / 07$ & SCUBA & $189^{\mathrm{a}}$ & 60 \\
\hline j & $\mathrm{Kv}$ & F & 107 & $27 / 08 / 06$ & $28 / 08 / 07$ & Trap survey & $96^{\mathrm{a}}$ & 150 \\
\hline
\end{tabular}

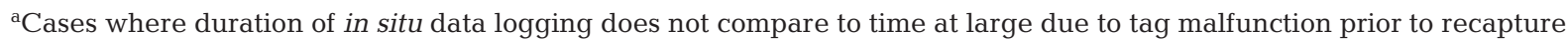

atures were measured at 1, 19 and $75 \mathrm{~m}$ in Flødevigen (Fig. 3). From April to July activity levels resumed (Fig. 6). Overall, the sea temperature experienced by the lobsters in their natural habitat (as recorded by the DSTs) dropped from a maximum of $18^{\circ} \mathrm{C}$ in September 2006 to a minimum of $2^{\circ} \mathrm{C}$ in early March 2007, and then increased again towards the summer of 2007 (Fig. 5). The seasonal trend in mean daily activity level (mean daily depth range) was significantly correlated to the seasonal trend in mean daily water temperature (Fig. $6 ; \beta_{0}=-2.93, \mathrm{SE}=0.20 ; \beta_{1}=1.74, \mathrm{SE}=0.09 ; \mathrm{p}<$ 0.0001 , model $\mathrm{r}^{2}=0.55$ ).

On a diel basis, the lobsters tended to be more active during nighttime than during daytime (Fig. 4), and were significantly more active at nighttime during the $26 \mathrm{~d}$ for which we had overlapping data from 9 females (Fig. 7A; $\beta_{0}=-4.51, \mathrm{SE}=1.59 ; \beta_{1}=0.57, \mathrm{SE}=0.08$; $t$-value $=7.35, \mathrm{df}=457, \mathrm{p}<0.0001)$. There was also a significant effect of day of the year $\left(\beta_{2}=0.01, \mathrm{SE}=0.01\right.$; $t$-value $=2.85, \mathrm{df}=457, \mathrm{p}=0.0046)$, indicating that there was more variation between daytime and nighttime activity levels later in the $26 \mathrm{~d}$ period. For comparison, we tested the interaction between 'time of day' and 'day of year', which also indicated more variation later in the period, although the interaction effect was not statistically significant at the 0.05 level (slope: $0.018 \pm 0.010 \mathrm{SE}, \mathrm{p}=0.074$ ). The difference between the mean nighttime and daytime depths suggested a tendency for lobsters to record a more shallow mean depth during nighttime versus daytime over the $26 \mathrm{~d}$ for which we had overlapping data from 9 females, although this difference was not significant at the 0.05 level (Fig. 7B; $\beta_{0}=33.31, \mathrm{SE}=7.36 ; \beta_{1}=-0.65, \mathrm{SE}=$ $0.34 ; t$-value $=-1.91, \mathrm{df}=457, \mathrm{p}=0.0563)$, and there was no significant effect of day of the year $\left(\beta_{2}=-0.01\right.$, $\mathrm{SE}=0.02 ; t$-value $=-0.57, \mathrm{df}=457, \mathrm{p}=0.5685)$.

\section{DISCUSSION}

In the present study, application of archival DSTs logging in situ depth and temperature demonstrated clear seasonal and diel patterns in the activity of European lobsters Homarus gammarus in the Skagerrak. This method has previously been applied in long-term studies on other large decapod crustaceans: the Dungeness crab Cancer magister (depth, temperature, salinity; Curtis \& McGaw 2008) and the American lobster $H$. americanus (temperature; Cowan et al. 2006). However, to the best of our knowledge, these are the first direct measurements of depth obtained from freely behaving lobsters.

We found that the recaptured individuals displayed high site fidelity between the time of capture and recapture. This behaviour has previously been demonstrated based on traditional mark-recapture methods (Dannevig 1936, Smith et al. 2001, Agnalt et al. 2007) and electromagnetic telemetry (Smith et al. 1998, 1999) and suggested by acoustic telemetry (van der Meeren 1997). However, although limited net horizontal displacement between the time of capture and recapture is a good indicator of site fidelity, our results clearly demonstrate that this measure displays a poor picture of actual movement between capture and recapture, when viewed in combination with the recorded depth profiles. For example, Lobsters $\mathrm{c}$ and $\mathrm{h}$ will have had to venture further in order to attain the maximum depths recorded by the DST (see Figs. 1 \& 5). The telemetry data from the Flødevigen reserve confirmed that Lobsters $\mathrm{c}$ and $\mathrm{f}$ both ventured out of the reserve and thus farther than the distance suggested by the mark-recapture data (E. Moland unpubl. data, to be reported elsewhere). Individual size and time at large had no effect on net horizontal displacement. However, the limited sample size $(n=10)$ in- 


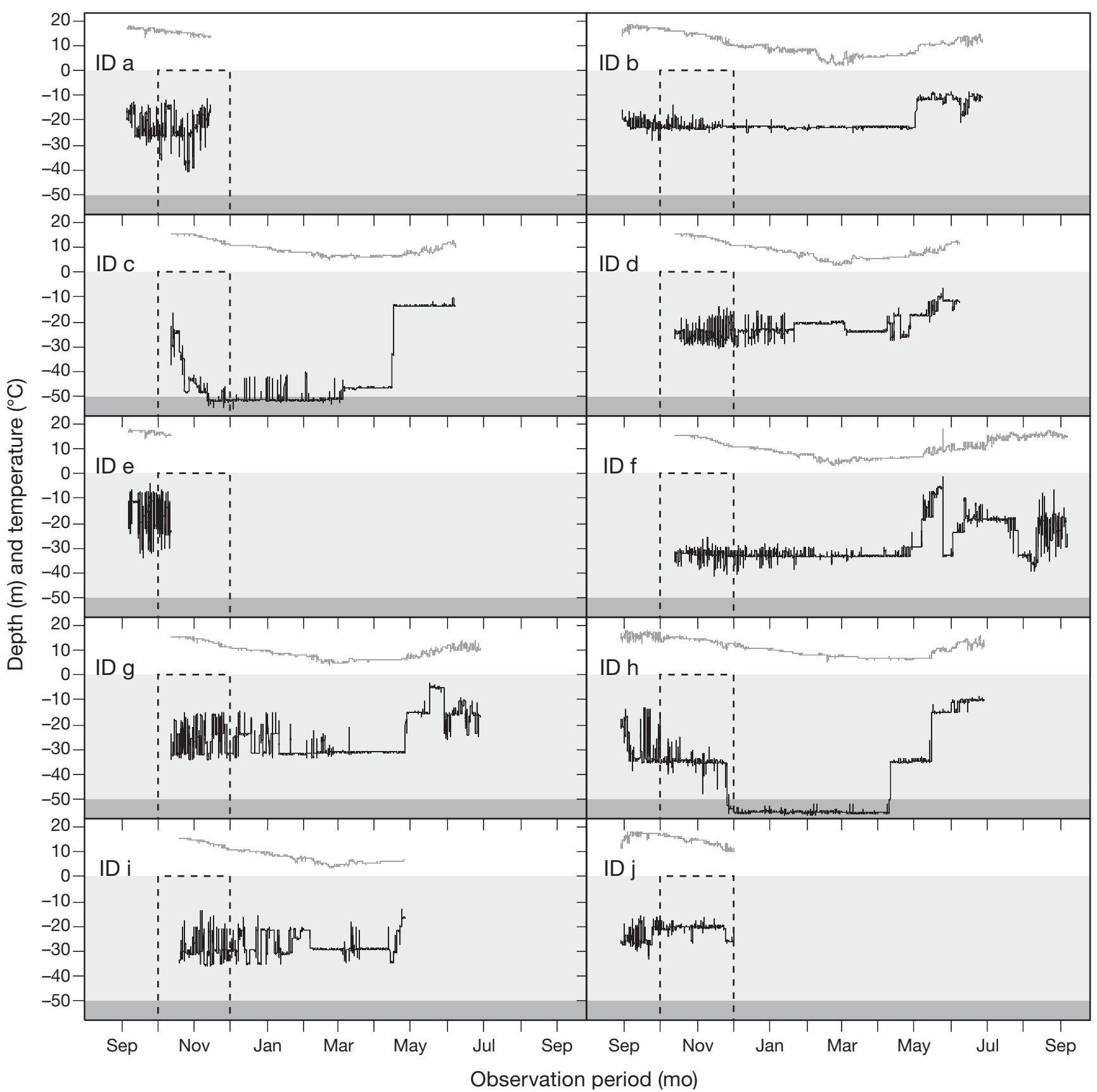

Fig. 5. Homarus gammarus. Depth (black line) and temperature (grey line) recorded by 10 (ID a to j, see also Table 2) freely behaving European lobsters in marine reserves in the coastal Skagerrak from September 2006 to September 2007, also showing the depth range available within reserves (light grey shading), as well as deeper neighbouring habitats outside reserves (dark grey shading). Dashed box indicates the duration of the harvest season outside the reserves. Tick marks on the $x$-axis mark the beginning of each month

cluded in the present study means that only major effects can be detected statistically.

In the present study, change in depth (depth range) was used as a measure of activity. The seasonal trend in this behavioural metric (mean depth range) was correlated to the seasonal trend in mean water temperature from September 2006 to July 2007. Variation in mean water temperature explained $55 \%$ of the variation in mean activity during this period (Fig. 6). In general, activity was high, albeit declining, from midSeptember through January, but with considerable variation among individuals. Through February and March, lobsters exhibited a state of minimal change in depth, coinciding with the period during which the 


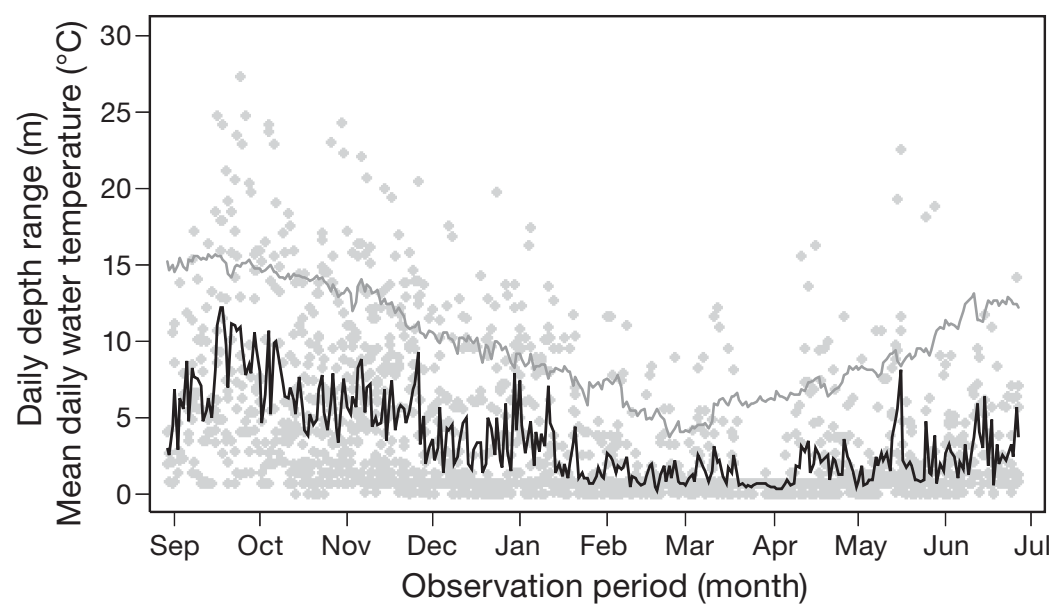

Fig. 6. Homarus gammarus. Seasonal variation in activity level of European lobsters within marine reserves in the coastal Skagerrak from September 2006 to July 2007, showing individual daily ranges of recorded depth (light grey symbols) and average values (black line). The dark grey line is the mean sea temperature calculated from measurements at 1, 19 and $75 \mathrm{~m}$ in Flødevigen. The observation period was set to the time during which we had data from $\geq 2$ individuals. Tick marks on the $x$-axis mark the beginning of each month
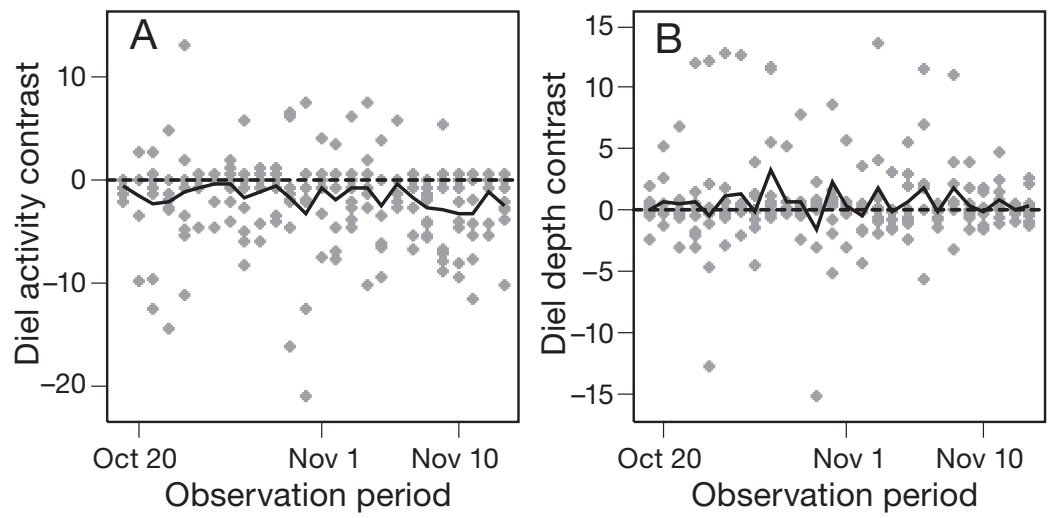

Fig. 7. Homarus gammarus. Diel variation in (A) activity and (B) recorded depth in 9 female European lobsters within marine reserves in the coastal Skagerrak during 26 d from October to November 2006. Grey symbols: individual observations; solid lines: average values. Diel activity contrast $(\mathrm{A})$ is the difference between the depth range recorded during daytime (09:00 to 15:00 h) and the depth range recorded during the following night (21:00 to 03:00 h). Negative numbers indicate that a greater depth range was recorded during night than during daytime. Diel depth contrast (B) is the difference between the mean depth recorded during daytime and that recorded during the following night. Positive numbers indicate that lobsters were found in more shallow water during the night

lowest temperatures were recorded by lobsters and measured in the water column in Flødevigen. However, most individuals exhibited bouts of activity even during the coldest periods (Fig. 5). A short period of near zero diel depth change in all individuals was evident from late March to early April (Fig. 6), coinciding with the spring mixing when the entire water column was $\sim 6^{\circ} \mathrm{C}$ in Flødevigen (Fig. 3). This, in turn, was followed by an increase in depth change from April to May, coinciding with sea temperatures having risen above $6^{\circ} \mathrm{C}$ throughout the water column in Flødevigen (see Fig. 3). The general seasonal pattern revealed herein is in agreement with a previous field study reporting seasonal variation in the activity pattern of European lobster (Smith et al. 1999). Those authors used electromagnetic telemetry to measure seasonal changes in locomotor activity and body movements of lobsters on an artificial reef in Poole Bay, southern England, UK. They found that activity, quantified as daily inter-reef unit movements, decreased with declining temperature during September through January until it was virtually extinguished in all size groups with temperatures $<10^{\circ} \mathrm{C}$. It is interesting to note that all the lobsters for which we have prolonged data (all female) either moved permanently into, or made excursions into, shallower areas at a time when surface waters in Flødevigen began to warm up in May $\left(7\right.$ to $9^{\circ} \mathrm{C}$; see Figs. 3 $\& 5)$. This behaviour could be driven by greater food availability in shallower areas as temperatures increase. Alternatively, lobsters might seek warmer water to accelerate metabolism, incubation of eggs, or maturation of internal gonad tissue. However, at present, we lack sufficient information to pinpoint the ecological mechanism driving this behaviour. Inshore-offshore migrations in American lobsters have been explained by an affinity to the warmest possible seasonal temperatures within the bounds of their thermal preference (Campbell \& Stasko 1986), although Cowan et al. (2006) suggested that migrations undertaken by ovigerous American lobsters might serve to reduce variation in their thermal regime. Trends in the diel depth range suggest that lobsters were clearly more active during the night than during daytime. Moreover, we found a weak effect of time of day on mean depth, suggesting that lobsters occupied slightly deeper areas during daytime throughout the same period. This indicates that lobsters adopted a behaviour, according to which they took shelter in deeper habitat during daytime and, on average, foraged in slightly shallower habitat during nighttime in this period. The general activity pattern revealed herein is 
in agreement with previous work examining the diel rhythms in European lobster behaviour: (1) Mehrtens et al. (2005) found that juvenile European lobsters exhibited distinct nocturnal exploration behaviour in a laboratory maze; and (2) in a field study, Smith et al. (1999) showed that locomotor activity followed an almost exclusively nocturnal pattern during the months in which lobsters are active. Integral tilt switches in the electromagnetic tags used in their study indicated that body movements followed a similar diel pattern, but with less abrupt changes, suggesting that lobsters also maintained a certain degree of activity during daytime. In American lobster, laboratory work has demonstrated activity patterns strongly influenced by endogenous circadian rhythmicity (e.g. Jury et al. 2005). However, the results of the present and other studies have shown large amounts of variability in the extent to which this pattern is expressed under natural conditions. In their telemetry study, Golet et al. (2006) found that 5 out of 44 American lobsters $(11 \%)$ moved significantly more during the day than during nighttime. Laboratory work conducted by Ulrich (1998) showed that European lobsters remained within shelters for $95 \%$ of the time during a $54 \mathrm{~h}$ permanent illumination period. In contrast, lobsters spent about $1 \%$ of the time within shelters during a subsequent $89 \mathrm{~h}$ dark period. However, as with American lobster and most species, the existence of an endogenous circadian clock in European lobster is likely.

The present study provides empirical field data that are potentially valuable for deciding on an appropriate size and location for future marine reserves to protect this species. Importantly, for 2 of the lobsters (ID c and h) in the present study, depths that showed that they must have left the reserve areas for prolonged periods during winter were recorded. In addition, a third lobster (ID a; a non-ovigerous female) left the Flødevigen reserve and was recaptured by a lobster fisher outside reserve borders (in shallow water) early in the study (see Fig. 1). Lobster c, tagged in the Flødevigen reserve, spent most of the period from mid-November to early March ( 3.5 mo) deeper than $50 \mathrm{~m}$ (55 m maximum depth), although several excursions were made into slightly shallower water during this period (see Fig. 5). This lobster (an ovigerous female) would surely have had to leave the reserve in order to attain depths below $50 \mathrm{~m}$, as there are no areas this deep within the Flødevigen reserve (see Fig. 1). In the smaller Kvernskjær reserve, one of the lobsters (ID h) spent a period of similar duration (end of November to early April, 4 mo) entirely below $50 \mathrm{~m}$ (57 m maximum depth; see Fig. 5). The maximum depth attained by this lobster (a non-ovigerous female) corresponds to the maximum depth found in the deep narrow channel flanking the western side of the Kvernskjær reserve (see Fig. 1), outside the re- serve area. All lobsters except 1 individual (ID b) recorded depths down to or below $30 \mathrm{~m}$ for shorter or longer periods during the observation period.

The present study suffered from a limited sample size due to the difficulty posed by having to recapture lobsters to obtain data from archival tags. Future studies would benefit from depth sensory telemetry technology, allowing continuous monitoring of a greater number of lobsters. However, any study involving attachment of tags that are lost during moulting will have limitations with regard to testing the effectiveness of long-term management measures such as marine reserves. Previous studies have successfully assessed the effectiveness of closed areas for large decapods with tag-return methodology, e.g. blue crab Callinectes sapidus (Lambert et al. 2006) and spiny lobster Jasus edwardsii (Freeman et al. 2009). These studies have underlined the importance of habitat as an essential underlying mechanism driving movement patterns in the species studied. The existence and configuration of the habitat preferred by lobsters during different stages of the life cycle and the corridors for movement between such habitats should thus be considered when designing marine reserves to match management objectives. Studies designed to quantify longterm home range behaviour in European lobsters might prove particularly useful in this regard.

In conclusion, the observations presented herein suggest that future reserves for European lobster should be designed to include deeper habitat (30 to $50 \mathrm{~m}$ ) in areas where such habitat exists when the management objective is long-term protection.

Acknowledgements. Members of the Institute of Marine Research dive team, P. Baardsen and Ø. Paulsen, deserve thanks for valued assistance during underwater field work. We thank S. Einum and R. N. Lipcius for providing valuable comments on a previous version of this manuscript and 4 anonymous referees for thoughtful reviews that greatly improved the quality of the present work. The tagging procedure was reviewed and approved by the local animal welfare officer. This study was financed by the Research Council of Norway through Grants 173432/S40 and 201917/V50 and by the EU and the Norwegian government through the 'INTERREG III A' programme.

\section{LITERATURE CITED}

Agnalt AL, Kristiansen TS, Jorstad KE (2007) Growth, reproductive cycle, and movement of berried European lobsters (Homarus gammarus) in a local stock off southwestern Norway. ICES J Mar Sci 64:288-297

Campbell A, Stasko AB (1986) Movements of lobsters (Homarus americanus) tagged in the Bay of Fundy, Canada. Mar Biol 92:393-404

Childress JM, Jury SH (2006) Behaviour. In: Phillips BF (ed) Lobsters: biology, management, aquaculture and fisheries. Blackwell Publishing, Oxford, p 78-112

> Cook RM, Sinclair A, Stefánsson G (1997) Potential collapse of 
North Sea cod stocks. Nature 385:521-522

Cooper RA, Uzmann JR (1971) Migration and growth of deepsea lobster, Homarus americanus. Science 171:288-290

Côté IM, Mosqueira I, Reynolds JD (2001) Effects of marine reserve characteristics on the protection of fish populations: a meta-analysis. J Fish Biol 59:178-189

> Cowan FC, Watson WH, Solow AR, Mountcastle AM (2006) Thermal histories of brooding lobsters, Homarus americanus, in the Gulf of Maine. Mar Biol 150:463-470

Curtis DL, McGaw IJ (2008) A year in the life of a Dungeness crab: methodology for determining microhabitat conditions experienced by large decapod crustaceans in estuaries. J Zool (Lond) 274:375-385

Dannevig A (1936) Lobster and lobster culture. Report on Norwegian fishery and marine investigations, Vol 4, No 12. Director of Fisheries, Bergen (in Norwegian)

Freeman DJ, MacDiarmid AB, Taylor RB (2009) Habitat patches that cross marine reserve boundaries: consequences for the lobster Jasus edwardsii. Mar Ecol Prog Ser 388:159-167

Fromentin JM (2009) Lessons from the past: investigating historical data from bluefin tuna fisheries. Fish Fish 10: 197-216

Game ET, Grantham HS, Hobday AJ, Pressey RL and others (2009) Pelagic protected areas: the missing dimension in ocean conservation. Trends Ecol Evol 24:360-369

Golet WJ, Scopel DA, Cooper AB, Watson WH (2006) Daily patterns of locomotion expressed by American lobsters (Homarus americanus) in their natural habitat. J Crustac Biol 26:610-620

Haakonsen HO, Anoruo AO (1994) Tagging and migration of the American lobster Homarus americanus. Rev Fish Sci 2: 79-93

Halpern BS, Warner RR (2003) Matching marine reserve design to reserve objectives. Proc R Soc Lond B 270:1871-1878

Halpern BS, Walbridge S, Selkoe KA, Kappel CV and others (2008) A global map of human impact on marine ecosystems. Science 319:948-952

Jury SH, Chabot CC, Watson III WH (2005) Daily and circadian rhythms of locomotor activity in the American lobster, Homarus americanus. J Exp Mar Biol Ecol 318:61-70

Kramer DL, Chapman MR (1999) Implications of fish home range size and relocation for marine reserve function. Environ Biol Fishes 55:65-79

Lambert DM, Lipcius RM, Hoenig JM (2006) Assessing effectiveness of the blue crab spawning sanctuary in Chesapeake Bay using tag-return methodology. Mar Ecol Prog Ser 321:215-225

Lawton P, Lavalli KL (1995) Postlarval, juvenile, adolescent, and adult ecology. In: Factor JR (ed) Biology of the lobster Homarus americanus. Academic Press, New York, NY, p 47-81

Lowe CG, Topping DT, Cartamil DP, Papastamatiou YP (2003) Movement patterns, home range, and habitat utilization of adult kelp bass Paralabrax clathratus in a temperate no-take marine reserve. Mar Ecol Prog Ser 256:205-216

Editorial responsibility: Romuald Lipcius, Gloucester Point, Virginia, USA
McCullagh P, Nelder JA (1999) Generalized linear models. Chapman \& Hall/CRC, London

Mehrtens F, Stolpmann M, Buchholz F, Hagen W, Saborowski R (2005) Locomotory activity and exploration behaviour of juvenile European lobsters (Homarus gammarus) in the laboratory. Mar Freshw Behav Physiol 38:105-116

- Nesbø CL, Rueness EK, Iversen SA, Skagen DW, Jakobsen KS (2000) Phylogeography and population history of Atlantic mackerel (Scomber scombrus L.): a genealogical approach reveals genetic structuring among the eastern Atlantic stocks. Proc R Soc Lond B 267:281-292

Olsen EM, Carlson SM, Gjøsæter J, Stenseth NC (2009) Nine decades of decreasing phenotypic variability in Atlantic cod. Ecol Lett 12:622-631

Oug E, Vader W, Brattegaard T, Christiansen ME, Walseng B, Djursvoll P (2010) Crustacea. In: Kålås JA, Viken Å, Henriksen S, Skjelseth S (eds) The 2010 Norwegian Red List for species. Norwegian Biodiversity Information Centre, Trondheim, p 209-222

- Payne MR, Hatfield EMC, Dickey-Collas M, Falkenhaug T and others (2009) Recruitment in a changing environment: the 2000s North Sea herring recruitment failure. ICES J Mar Sci 66:272-277

Pettersen AR, Moland E, Olsen EM, Knutsen JA (2009) Lobster reserves in coastal Skagerrak - an integrated analysis of the implementation process. In: Dahl E, Moksness E, Støttrup J (eds) Integrated coastal zone management. Wiley-Blackwell Publishing, London, p 178-188

Pinheiro JC, Bates DM (2000) Mixed-effects models in S and S-plus. Springer, New York, NY

Russ GR, Cheal AJ, Dolman AM, Emslie MJ and others (2008) Rapid increase in fish numbers follows creation of world's largest marine reserve network. Curr Biol 18:R514-R515

Sale PF, Cowen RK, Danilowicz BS, Jones GP and others (2005) Critical science gaps impede use of no-take fishery reserves. Trends Ecol Evol 20:74-80

Smith IP, Collins KJ, Jensen AC (1998) Movement and activity patterns of the European lobster, Homarus gammarus, revealed by electromagnetic telemetry. Mar Biol 132: 611-623

Smith IP, Collins KJ, Jensen AC (1999) Seasonal changes in the level and diel patterns of activity in the European lobster Homarus gammarus. Mar Ecol Prog Ser 186:255-264

Smith IP, Jensen AC, Collins KJ, Mattey EL (2001) Movement of wild European lobsters Homarus gammarus in natural habitat. Mar Ecol Prog Ser 222:177-186

Triantafyllidis A, Apostolidis AP, Katsares V, Kelly E and others (2004) Mitochondrial DNA variation in the European lobster (Homarus gammarus) throughout the range. Mar Biol 146:223-235

Ulrich I (1998) Populationsgenetische und verhaltensbiologische Untersuchungen am Helgoländer Hummer, Homarus gammarus (L.). PhD dissertation, University of Hamburg

van der Meeren GI (1997) Preliminary acoustic tracking of native and transplanted European lobsters (Homarus gammarus) in an open sea lagoon. Mar Freshw Res 48: 915-921

Submitted: October 20, 2009; Accepted: February 22, 2011 Proofs received from author(s): May 2, 2011 